\title{
Evaluation of commercial products for protection and vigorous uptake of corn seed (Zea mays)
}

\section{Evaluación de productos comerciales para protección y un arranque vigoroso de semilla de maíz (Zea mays)}

\author{
Instituto Tecnológico Superior de Salvatierra \\ ID $1^{\text {st }}$ Author: Marcia Maribel, Martínez-Scott \\ ID $1^{\text {st }}$ Coauthor: Benjamín, Aguilar-Quintana
}

MARTÍNEZ-SCOTT, Marcia Maribel*† \& AGUILAR-QUINTANA, Benjamín

DOI: $10.35429 /$ JNAS.2019.19.6.32.39

Received Junio 21, 2019; Accepted December 30, 2019

\begin{abstract}
The objective of this research was to evaluate six commercial products used for the protection of seeds against pests and diseases. The products were Poncho, Nipsit Inside, Allectus 150, Allectus 722, Regent Ultra and Cruiser 350 FS. The experiment was established in the town of Puerta del Monte, belonging to the municipality of Salvatierra, Guanajuato, in a random block design with seven repetitions. The evaluated variables were plant height, stem diameter, root length, present populations of fall armyworm, cutworms, thrips, diabrotica and blind hens. The most efficient treatment on the protection of pests in the cultivation of maize in its stage V4-V6 (most vulnerable stage) was the Nipsit Inside, this according to the results that were obtained in the four weeks of evaluation and according to the statistic analysis. Nipsit Inside is an insecticide that showed a wide range of protection in addition to presenting superior yields and better quality in the ears. Poncho is the second alternative to be used because it has very similar characteristics to Nipsit Inside in most of the variables evaluated.
\end{abstract}

Pest, Fusarium oxysporum

\begin{abstract}
Resumen
El objetivo de esta investigación consistió en evaluar seis productos comerciales usados para la protección de semillas contra plagas y enfermedades. Los productos fueron Poncho, Nipsit Inside, Allectus 150, Allectus 722, Regent ultra y Cruiser 350 FS. El experimento se estableció en la localidad Puerta del Monte, perteneciente al municipio de Salvatierra, Guanajuato, en un diseño de bloques al azar con siete repeticiones. Las variables evaluadas fueron altura de planta, diámetro del tallo, longitud de la raíz, poblaciones presentes de gusano cogollero, gusanos trozadores, trips, diabrótica y gallinas ciegas. El tratamiento con mayor eficiencia sobre la protección de plagas en el cultivo de maíz en su etapa V4-V6 (etapa más vulnerable) fue el Nipsit Inside, esto de acuerdo con los resultados que se obtuvieron en las cuatro semanas de evaluación y de acuerdo al análisis estadístico. Nipsit Inside es un insecticida que mostró un amplio rango de protección además de presentar rendimientos superiores y mejor calidad en las mazorcas. Poncho es la segunda alternativa a ser utilizada ya que presenta características muy similares a Nipsit Inside en la mayoría de las variables evaluadas.
\end{abstract}

Insectos plagas, Fusarium oxysporum

Citacion: MARTÍNEZ-SCOTT, Marcia Maribel \& AGUILAR-QUINTANA, Benjamín. Evaluation of commercial products for protection and vigorous uptake of corn seed (Zea mays). Journal of Natural and Agricultural Sciences. 2019, 6-19: 32-39

*Correspondence to Author (mascott@itess.edu.mx)

$\uparrow$ Researcher contributing first author 


\section{Introduction}

Corn (Zea mays) is one of the most important and most researched crops in the world, with a productive potential that has been increasing year by year. During 1980, average yields of 1.8 $\mathrm{t}$ ha-1 were obtained, at present there are productions of $4.0 \mathrm{t}$ ha-1 (SIAP, 2018); that have been achieved thanks to the establishment of sustainable practices, linked to technological tools, to improve plant nutrition and keep control of pest and disease problems (SAGARPA, 2015).

Agricultural pests reduce crop production, reduce crop value and increase production costs (Agrios, 2008). Based on various studies, the Food and Agriculture Organization of the United Nations (FAO) reports that, in corn losses are estimated at $34.8 \%$ ( $12.4 \%$ by insects, $9.4 \%$ by diseases and $13 \%$ by weeds (FAO, 2001).

Pathogens and seed pests in corn can be transmitted by itself or associated with it, as is the case with fungi, bacteria, viruses, insects, nematodes and weed seeds, which can be transported on the surface of the seed, inside and with the seed (Mezzalama, 2013).

In addition, the so-called soil pests and early pests occur in the cultivation of corn during the first 45 days, being the most common blind chicken (Phyllopaga criinita), diabrotic (D. virgifera, D. longicornis and D. undecimpunctata), trips (Frankliniella williamsi), aphids (Rhophalosiphum maidis and Melanaphis sacchari), cutting worms and cogollero (Colaspis sp, Agriotes sp and Spodoptera frugiperda) and some species of fungi of the genus Fusarium sp, which can prevent the emergence and establishment of the crop (CESAVEG , 2016; Espinoza et al., 2015; Figueroa-Rivera et al., 2010; Marin et al., 2008) For this, the use of insecticides and fungicides is recommended as a treatment for seeds, which can be used alone or in combination with inoculants, growth regulators, fertilizers and fertilizer improvers to solve or prevent a good number of problems of pests, diseases and deficiencies. nutritional; as well as to improve plant growth (Hopkins, 2016).
The treated seeds allow a healthy development from germination, in a uniform and uninterrupted way, thus facilitating an even and vigorous start of the corn (Pérez, 2018). However, sometimes these protections are not efficient due to pests that occur in a specific geographical area or because some of those products have not been tested (CESAVEG, 2015).

The problems of pests and diseases in corn that occur during the early stages (sowing, emergency and development) and that cause severe damage, because they do not have an adequate plant protection period, prevent Salvatierra Guanajuato farmers from establishing their crops with a healthy, uniform and vigorous start. Thus, as the objective of this research was, to evaluate six commercial products (some of them of new generation) that present the greatest period of protection of the seed against pests and soil diseases.

\section{Methodology to be developed}

Study area. This research was carried out in the municipality of Salvatierra, Gto., Located between the coordinates $-101.02^{\prime} 47^{\prime \prime} 22$ and 20.26'11"11, with an altitude of 1720 masl, whose maximum temperature is $33.4^{\circ} \mathrm{C}$, the average Annual is $18.1^{\circ} \mathrm{C}$ and the minimum $2^{\circ}$ C. Rainfall is 730 millimeters per year, predominantly the dark Vertisol Pelvic soil, generally with clayey texture and average depth of $60 \mathrm{~cm}$.

Establishment of the crop. The preparation of the land was carried out with a fallow at $35 \mathrm{~cm}$ depth, two dredge steps, lifting of boards at $20 \mathrm{~cm}$, the planting was carried out on June 10, establishing the BD54 hybrid (BIDASEM). The experimental area per treatment was $150 \mathrm{~m}$ long and $24 \mathrm{~m}$ wide, with a planting density of 90 thousand plants per hectare.

Experimental design. A randomized block design with seven repetitions was established, selecting 20 plants per repetition (Herrera et al., 2009). Data analysis was performed with the Statistic Analytic System statistical software (SAS, 1990).

The seed used was submerged in the following treatments: 
T1 Witness (untreated seed)

T2 Nipsit inside (i.a. Clothianidine) $10.56 \mathrm{ml} / 10.5$ ml of water

T3 Poncho 600 FS (i.a. Clothianidine) $7.04 \mathrm{ml} / 10.5$ ml of water

T4 Allectus 150 TS (i.a. Biphentrine / Imidacloprid) $70.4 \mathrm{ml}$ (direct immersion)

T5 Crusier 350 FS (i.a. Thiamethoxam) $7.04 \mathrm{ml} /$ $10.5 \mathrm{ml}$ of water

T6 Regent ultra (i.a. Fipronil) $7.04 \mathrm{ml} / 10.5 \mathrm{ml}$ of water

T7 Allectus 722 TS (i.a. Biphentrine / Imidacloprid) $16.90 \mathrm{~g}$ (direct on the seed).

Variables to evaluate. Germination time, Emergency Speed Index (IVE) (Maguire, 1962) and germination percentage (PG) were evaluated. The means of the treatments were compared through the Tukey $\alpha=0.05$ comparison test. The results were expressed as a percentage and their data were transformed with the formula arc $\backslash$ sine $=\backslash$ sqrt $\{\% / 100\}$. The variables of plant height, stem diameter and root length, (measured in $\mathrm{cm}$ from the root neck to the apex of the last leaf). For the vigor and level of damage a scale already established by Bayer was used (with values from 1 to 5,1 being for plants with minimal damage and 5 for plants with greater damage; contrary to vigor, number 1 was assigned for greater vigor and 5 for plants with less vigor).

The number of healthy plants, percent of finished plants and percent of plants with symptoms of fusariosis, ear weight, number of grains per ear, ear weight and yield estimate per hectare were also evaluated. As well as the presence of blind, diabrotic hen, cutting worms, thrips and cogollero worm, through visual sampling.

Agronomic crop management. An irrigation of aniego was supplied before sowing and three of aid with a sheet of $20 \mathrm{~cm}$ during the development of the crop. Weeding with weeds and weed management.

Nutrition of the crop. $150 \mathrm{~kg} / \mathrm{ha}$ of ammonia and $200 \mathrm{~kg} / \mathrm{ha}$ of Nutrigen triple 17 were applied to the planting (N 17\%, P 17\%, K $17 \%$ ). During the development of the crop, 2 doses of $200 \mathrm{~kg} /$ ha of urea were combined with $200 \mathrm{~kg} / \mathrm{ha}$ of ammonium sulfate, this was in stages V6 and V9.

\section{Results}

Germination days. Although 50\% of the seeds inoculated with Nipsit inside, Poncho and Regent ultra, had the least number of germination days, the results indicate that there were no differences between treatments. The germination of the control was the latest. This experiment was repeated during 2017 and 2018, presenting similar results.

Germination percentage. The germination percentage for all treatments was $98 \%, 2 \%$ were non-viable or vain seeds.

Emergency speed index. The behavior for this variable was similar between treatments. The emergency on the seventh day of the plants inoculated with Nipsit inside, Poncho and Regent ultra was 63\%, 61\% and $58.9 \%$ respectively. The emergency percentages during the eighth and ninth day were $25 \%$ and $10 \%$ for Nipsit inside, 20\% and 18\% for Poncho and 26\% and $13.9 \%$ for Regent ultra. The emergency percentage during the eighth, ninth and tenth day for Allectus 150 TS was $54 \%, 26 \%$ and $18 \%$. For Crusier 57\%, 28\% and 15\% and for Allectus 722 TS 59\%, 30\% and $8 \%$. The witness presented a $58 \%$ emergency on the ninth day and completed his emergency on the tenth. The remaining percentage did not emerge.

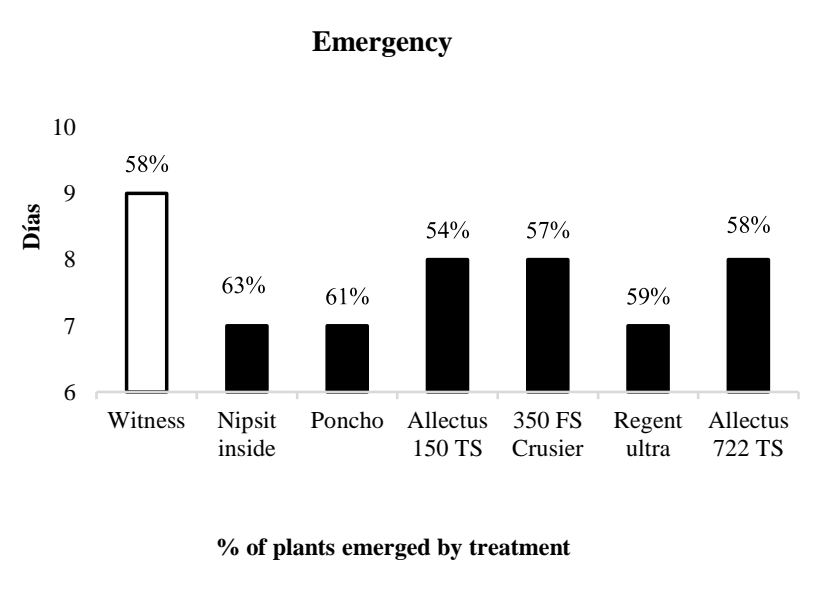

Graphic 1 Days to seed emergency

Weekly growth. No weekly growth differences were found between plants treated with insecticides / fungicides at an $\alpha=0.05$ for five consecutive weeks, except the control. 


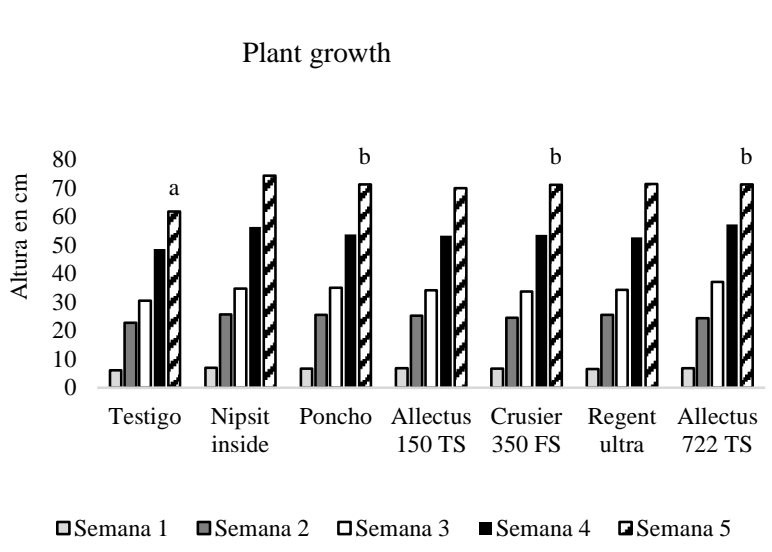

Graphic 2 Weekly plant growth behavior

Final height of the plant. Even though the plants treated with Nipsit inside reached a final height of $2.51 \mathrm{~m}$, there are no statistical differences $(\mathrm{P}>0.5)$ with the other treatments except the witness who reached a final height of $2.23 \mathrm{~m}$.

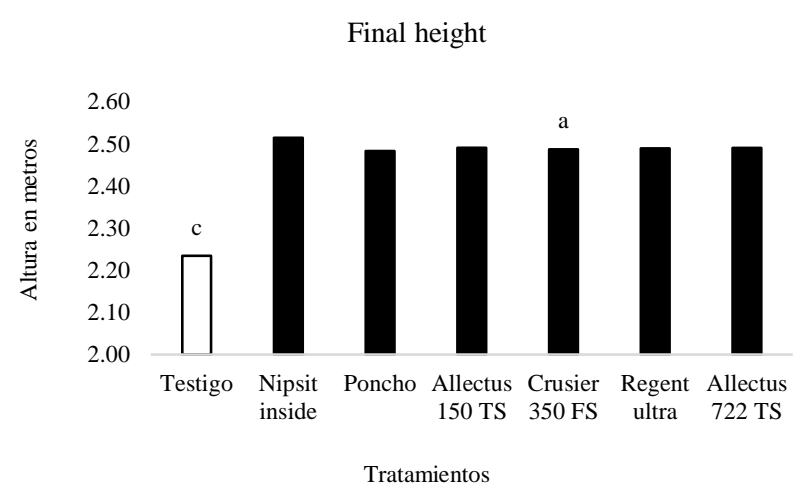

Graphic 3. Final height of the plant

Root Length The data in the following graph show a similar behavior of longitudinal root growth between treatments during the first week, however, from the second week a slight superiority is observed with respect to the control. The outstanding treatment was Nipsit inside, while the plants treated with the Poncho, Allectus 150 TS, Crsier 350 FS, Regent Ultra and Allectus 722 behaved similarly during the second to the fifth week.

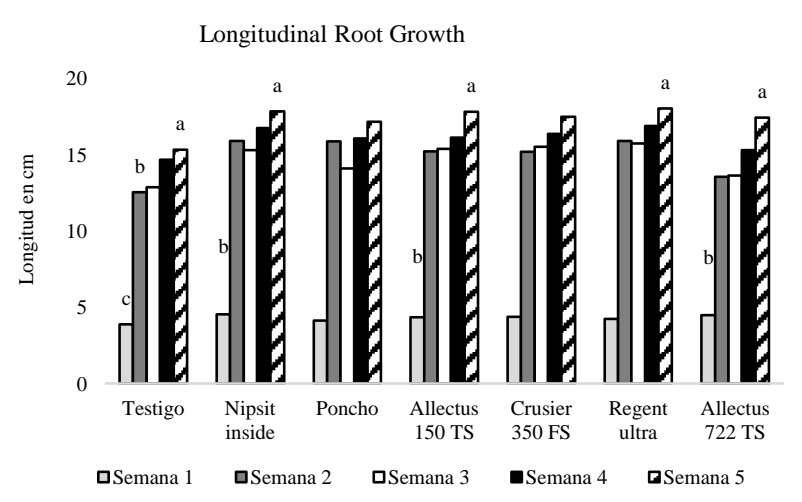

Graphic 4 Weekly root growth stockings
Stem diameter According to the results obtained in the Tukey test at a $\mathrm{P}<0.5$, the plants treated with Nipsit inside, showed superiority in the thickness of the stem during the five weeks evaluated, followed by plants treated with Poncho and Allectus 722, while, the remaining treatments and the control had the smallest diameter (Graphic 5).

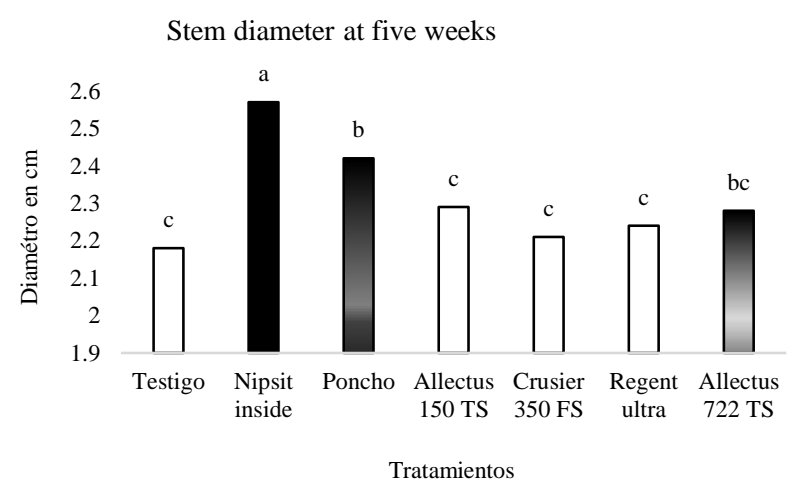

Graphic 5 Comparison of stem diameter averages at five weeks

Vigor of the plant. The results indicate that even when the control plants had the lowest vigor, there were no differences between treatments. Therefore, any commercial product evaluated that you wish to use will not have an influence for this variable under the conditions established in the experiment.

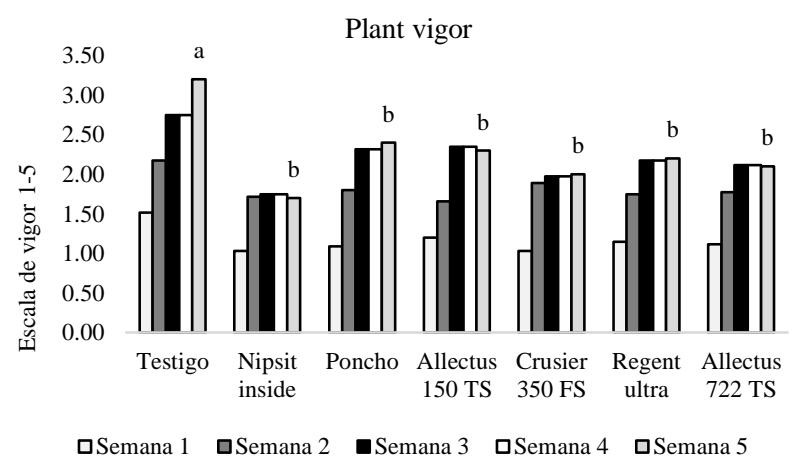

Graphic 6 Comparison of stem diameter averages at five weeks

Just plants. One of the problems that occur in the maize of the Guanajuato basin, is the end of the plants produced by the action of stemcutting insects, combined with the rains and the wind; interfering with the harvest at the time of harvest. The following graph shows the percentage of finished plants, where the control reached $30 \%$ of the total population, contrary to the plants treated with Nipsit Inside and Poncho, which obtained 8 and $9 \%$ respectively from the end of plants. 


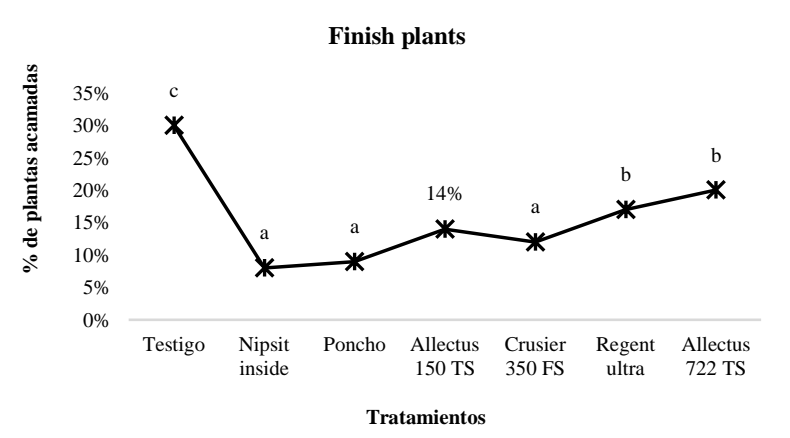

Graphic 7 Percentage of finished plants

Plant damage level. Figure eight shows the results obtained on the level of damage to the plant, caused by the presence of pests and diseases; observing that the five treatments exercised similar protection in the seed, except for Allectus 722 TS and the witness, who showed higher damage scales of 2.06 and 2.8 at the fifth week respectively.

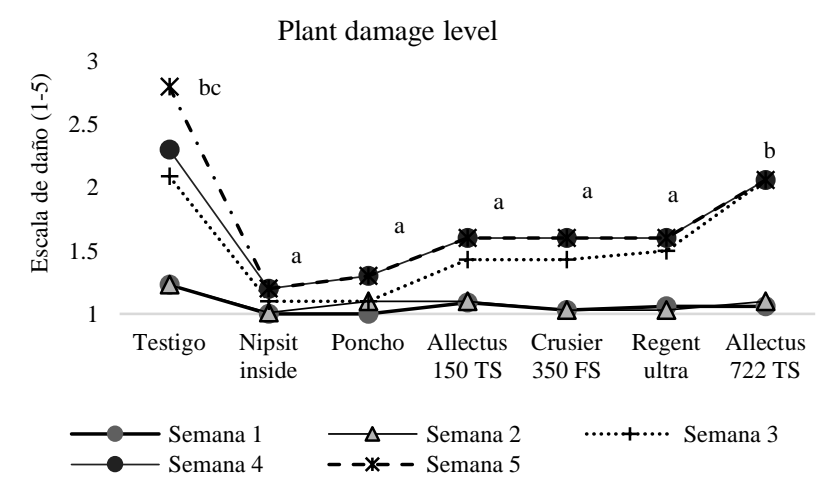

Graphic 8 Average damage level of pests and diseases presented in the crop

\section{Fusarium oxysporum (Schlecht)}

infestation. The control presented $21 \%$ of plants with symptoms of fusariosis, data that were corroborated through root samples collected at 60 days and incubated in moist chambers; from the mycelial growth the fungus was isolated and identified. The plants treated with Nipsit Inside and Poncho had the lowest percentage of chlorotic plants or with symptoms of the disease.

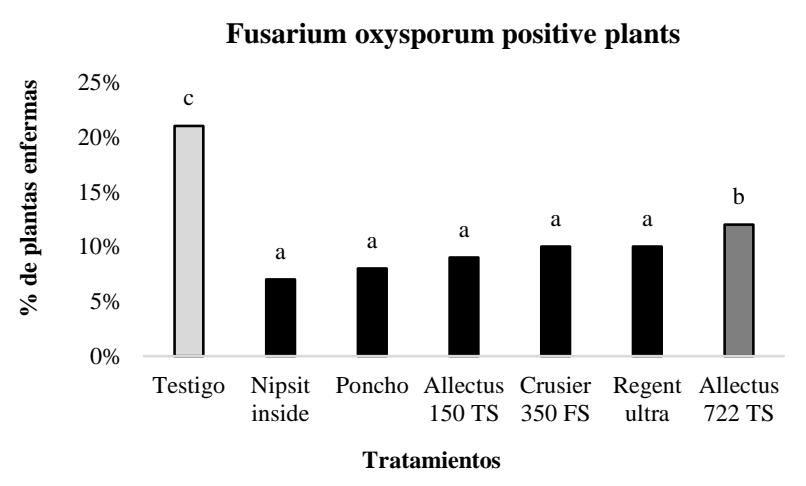

Graphic 9 Percent of plants positive to F. oxysporum
It is important to mention that agricultural soils in southeastern Guanajuato where corn is continuously established, are being severely infected by the horizontal and vertical distribution of Fusarium, this is perhaps the result of the use of contaminated machinery, which is a way to spread spores or perhaps It is due to the slope presented by agricultural plots, which are irrigated by gravity.

Population of cogollero worm (Spodoptera fugiperda Smith). From the second week there was a presence of cogollero worm. The plants treated with Nipsit inside and Poncho showed the lowest populations of this pest, while the rest of the plants showed similarity between the number of individuals present. The largest population of insects was recorded in the control according to the comparison of means (Tukey $\mathrm{P}<0.05$ ).

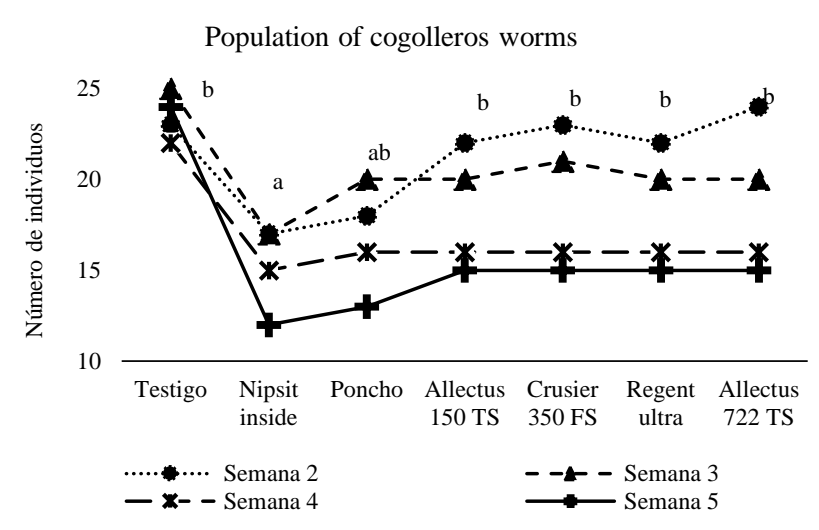

Graphic 10 Presence of cogollero worm for five consecutive weeks

Population of cutting worms (Agrotis sp Hufnagel). There were no statistical differences with respect to the population of cutting worms, except for the witness, in whom the greatest number of individuals present since the first week was registered (Tukey $\mathrm{p}<0.05$ ).

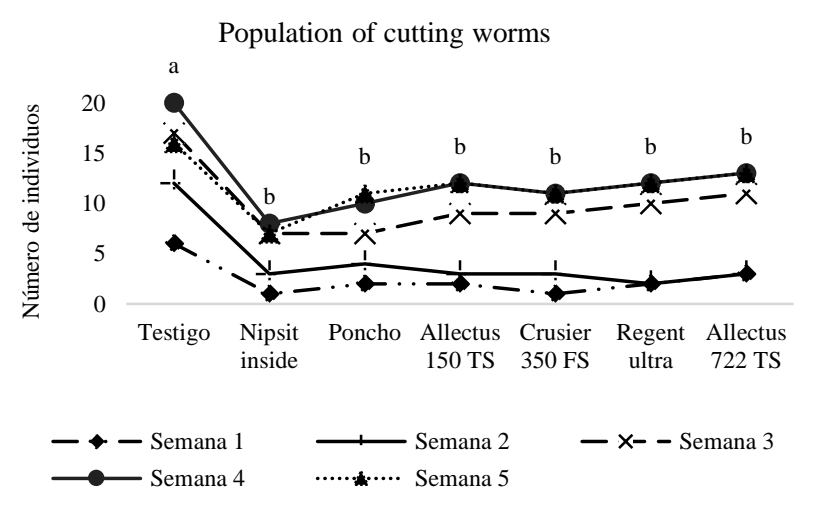

Graphic 11 Average population of Agrotis sp recorded for five consecutive weeks 
Diabrotic population (Diabrotica sp Germar). The effect of the insecticides / fungicides on the diabrotic, showed that the treatments behaved in a similar way, except for the witness who presented the largest number of beetles in their experimental units.

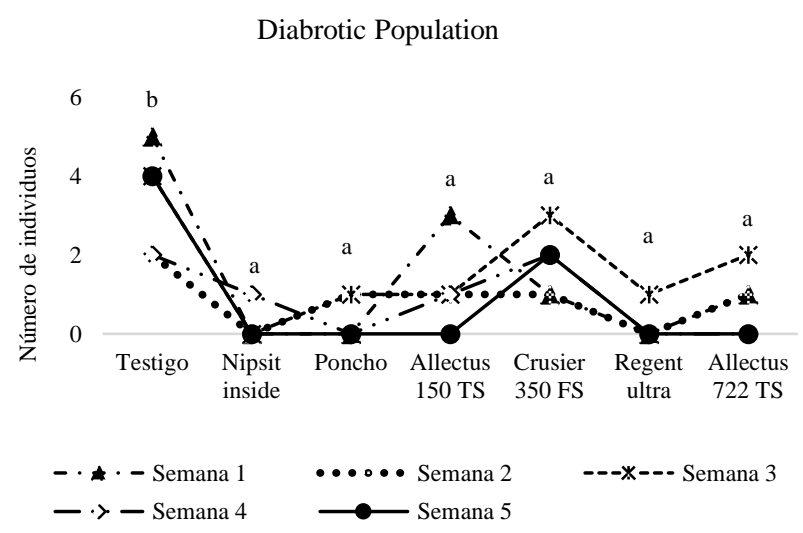

Graphic 12 Average population of registered diabrotics for five weeks

Population of blind hens. The lowest population of blind hens occurred in plants treated with Nipsit inside and Crusier 350 FS, while the largest number was for untreated plants. Allectus 150 TS did not show a behavior similar to the rest of the pesticides. The average blind hens for five weeks were 48, 1, 7, 14, 1, 5 and 7 for the witness, Nipsit inside, Poncho, Allectus 150 Ts, Crusier 350 FS, Regent Ultra and Allectus 722 TS consecutively.

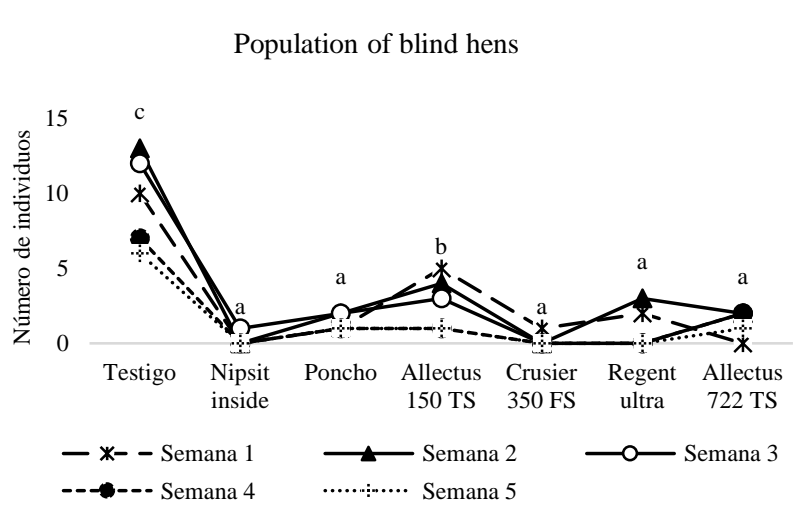

Graphic 13 Incidence of blind hens in treatments for five consecutive weeks

Population of thrips (Frankliniella williansi Hood). Nipsit Inside exercised effective control over the thrips population, registering 155, 262, 225, 90 and 35 individuals during the first, second, third, fourth and fifth week respectively (Tukey $\mathrm{P}<0.5$ ). In turn, the control flowers housed the largest population of thrips with values of 278, 581, 363, 250 and 187 insects respectively.

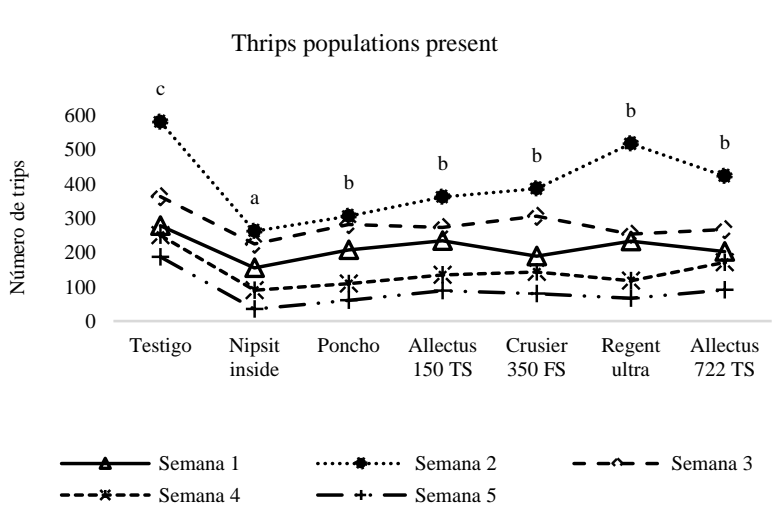

Graphic 14 Population means of thrips (Frankliniella occidentalis)

\section{Performance variables}

Plant population The data indicate that the Nipsit inside treatment allowed the establishment of the largest number of plants per hectare that was 88,750 , followed by Poncho with 88,500 and finally the control with a population of 86,500 (Graphic 15).

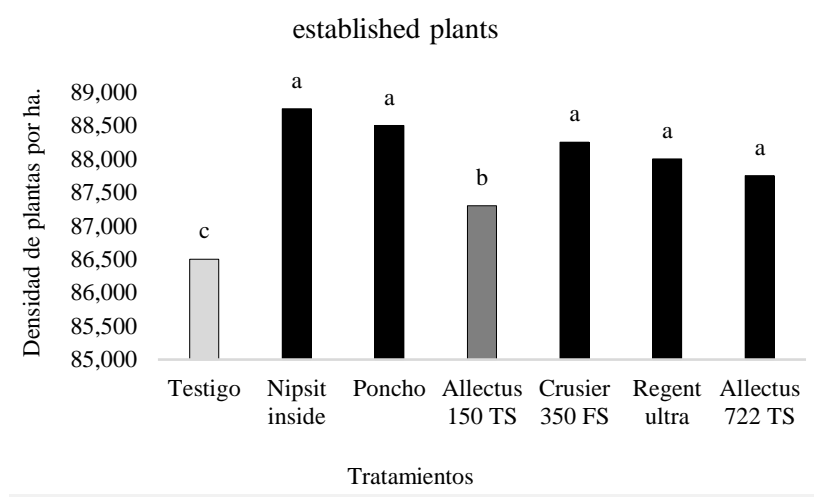

Graphic 15 Final plant establishment (treatment means)

Grains per row, grains per cob and weight of the cob. Table 1 shows the values of grains per row, grain weight, ear weight and yield per hectare. In the variable grains per row there were no differences between treatments, however, for grains per ear and cob weight, Nipsit inside stood out (Tukey $\alpha=0.05$ ).

\begin{tabular}{|l|cr|cr|cr|}
\hline \multicolumn{1}{|c|}{ Treatment } & $\begin{array}{c}\text { Grain/ } \\
\text { Row }\end{array}$ & $\begin{array}{c}\text { Grain/ } \\
\text { cob g }\end{array}$ & $\begin{array}{c}\text { Weight/ } \\
\text { cob g }\end{array}$ \\
\hline Witness & 30.69 & $\mathrm{a}$ & 430.9 & $\mathrm{c}$ & 193.5 & $\mathrm{c}$ \\
\hline Nipsit inside & 35.69 & $\mathrm{a}$ & 554.1 & $\mathrm{a}$ & 228.8 & $\mathrm{a}$ \\
\hline Poncho & 35.89 & $\mathrm{a}$ & 555.8 & $\mathrm{a}$ & 228.2 & $\mathrm{a}$ \\
\hline Allectus 150 TS & 35.51 & $\mathrm{a}$ & 534.2 & $\mathrm{~b}$ & 222.9 & $\mathrm{ab}$ \\
\hline 350 FS Crusier & 33.89 & $\mathrm{a}$ & 521.7 & $\mathrm{~b}$ & 216.6 & $\mathrm{ab}$ \\
\hline Regent ultra & 34.29 & $\mathrm{a}$ & 519.1 & $\mathrm{~b}$ & 216.2 & $\mathrm{ab}$ \\
\hline Allectus 722 TS & 32.91 & $\mathrm{a}$ & 505.4 & $\mathrm{~b}$ & 208.6 & $\mathrm{~b}$ \\
\hline $\begin{array}{l}\text { Gra / ha = Grains per row, Gra / m = grains per ear, Weight / } \\
\text { m = weight per ear. Equal letters do not show statistical } \\
\text { differences between treatments. }\end{array}$ \\
\hline
\end{tabular}

Table $1 \mathrm{Cob}$ variables that influence the final performance 
Yield per hectare. According to the data collected at the end of the harvest, it was estimated that the witness could obtain $16.7 \mathrm{~T} /$ ha of yield, while Nipsite inside would reach 18.7, Poncho 18.4, Allectus 159 TS 16.7, Cruisier 350 FS 16.8, Regente ultra 15.8 and Allectus 722 TS 14.7 T / he.

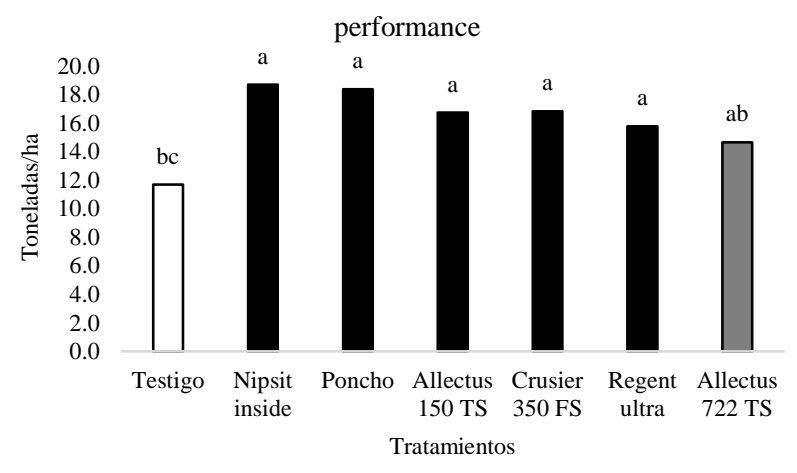

Graphic 16 Crop Yield Estimation

\section{Acknowledgments}

We thank the producers of Puerta del Monte and executives of the Instituto Tecnológico Superior de Salvatierra for the support and facilities provided for the development of this project.

\section{Conclusions}

The seeds inoculated with Nipsit inside, Poncho and Regent ultra germinated at seven days, with an index of $98 \%$, while the plants treated with Crusier 350, Allectus 159 TS and Allectus 722 TS were 8-10 days and the control of 9-10 days Similarly, seeds treated with Nipsit inside were superior in root length, and final plant height. The level of damage was lower in seed plants treated with Nipsit inside, while the control obtained the highest levels of damage. As for vigor there were no differences between treatments except the witness.

In the performance estimate, the treatments with lower yields were for Allectus 722 TS and the control. According to the data generated in this investigation; it is concluded that the treatment of seeds is an alternative that grants protection to the corn seed, in addition, of being an economic method, of easy manipulation and with a minimum impact on the environment. The results concluded that Nipsit inside and Poncho, showed an efficient control for soil pests and fusariosis, so it is advisable to use any of these products.

\section{References}

Agrios, G. N. 2008. Fitopatología. 5a Edición. Editorial Elsevier Academic Press. 948 p. ISBN: 9780080473789.

CESAVEG. (2016). Campaña de Manejo Fitosanitario de Maíz. Folleto técnico No. 8. Recuperado $\mathrm{http} / / / \mathrm{www}$.cesaveg.org.mx/html/ folletos /folletos_08/folleto_maiz_08.pdf.

Castillo Tovar, H., Espinoza Ramírez, M., Loera Gallardo, J., Almeida León, I. H. 2015. El tratamiento para siembra en PV. Boletín Electrónico. Año 1 No. 15. INIFAP. Centro de Investigación Regional del Noreste. Recuperado de:

http://www.inifapcirne.gob.mx/Eventos/2015/T RATAMIENTO $\% 20$ DE $\% 20$ SEMILLA $\% 20 \mathrm{ma}$ $\%$ C3\%ADz.pdf.

Dasgupta, P.R. H.M. Austenson. 1973. Relation between estimates of seed vigor and field performance in wheat. Canad. J. Plant Sci. 53: 43-46.

FAO. 2001. Efectos económicos de las plagas y enfermedades transfronterizas. En el estado mundial de la agricultura y la alimentación 2001. Organización de las Naciones Unidas para la Agricultura y la Alimentación. Roma, 2001. Recuperado de: http://www.fao.org/docrep/003/ x9800s/x9800s 16. htm\#TopOfPage.

Figueroa-Rivera, M. G., Rodríguez-Guerra, R., Guerrero-Aguilar, B. Z., González-Chavira, M. M., Pons-Hernández, J. L., Jiménez-Bremont, J. F., Ramírez-Pimentel, J. G., Andrio-Enríquez, E., Mendoza-Elos, M. (2010). Caracterización de Especies de Fusarium Asociadas a la Pudrición de Raíz de Maíz en Guanajuato, México. Revista mexicana de fitopatología, 28(2), 124-134. Recuperado en 05 de junio de 2018 , http//www scielo.org.mx/scielo.php?script=sci _arttext\&pid=S0185-

33092010000200005\&lng=es\&tlng=es.

Hopkins, M. 2016. Consideraciones para comenzar bien con tratamientos de semillas. Revista Productores de Hortalizas [En línea]. Recuperado de: http://www.hortalizas.com/proteccion-decultivos/ tratamiento-de-semillas/ 
Marín Jarillo, Antonio, \& Bujanos Muñiz, Rafael. (2008). Especies del complejo "gallina ciega" del género Phyllophaga en Guanajuato, México. Agricultura técnica en México, 34(3), 349-355. Recuperado en 05 de julio de 2018, de http://www.scielo.org.mx/scielo.php?script=sci _arttext\&pid=S0568-

$25172008000300010 \& \operatorname{lng}=$ es\&tlng= es.

Mezzalama, M. 2013. Sanidad de semilla: Promover la distribución segura de semilla de maíz y de trigo: Lineamientos generales. Tercera edición. México, D.F.: CIMMYT. ISBN: 978607-8263-23-3.

Pérez Domínguez, F. J. 2018. Tratamientos a la semilla para un arranque parejo y vigoroso del cultivo de maíz. Unisem. Consultado en línea: https://semillastodoterreno.com/2011/05/tratam ientos-a-la-semilla-para-un-arranque-parejo-yvigoroso-del-cultivo-de-maiz/.

SAGARPA. 2015. Agenda Técnica Agrícola de Guanajuato. Segunda edición. Secretaría de Agricultura, Ganadería, Desarrollo Rural, Pesca y Alimentación. ISBN volumen: 978-607-766842-8.

SIAP (Servicio de Información Agroalimentaria y Pesquera). (2018). Estadísticas de maíz en México.

http://infosiap.siap.gob.mx:8080/agricola_siap_ gobmx/AvanceNacionalSinPrograma.do. 